\title{
PENGARUH KOMUNIKASI ORGANISASI, KEPEMIMPINAN TRANSFORMASIONAL DAN KEADILAN ORGANISASI TERHADAP ORGANIZATIONAL CITIZENSHIP BEHAVIOR SERTA DAMPAKNYA PADA KINERJA DAN KOMITMEN ORGANISASIONAL
}

\author{
Meylinda Triyanthi ${ }^{1}$ \\ Made Subudi ${ }^{2}$
}

$\begin{aligned} & { }^{1} \text { Fakultas Ekonomi dan Bisnis Universitas Udayana, Bali, Indonesia } \\ & \text { e-mail: mtriyanthi@ gmail.com }\end{aligned}$
${ }^{2}$ Fakultas Ekonomi dan Bisnis Universitas Udayana, Bali, Indonesia

\begin{abstract}
ABSTRAK
Penelitian ini bertujuan untuk menganalisis dan menjelaskan pengaruh komunikasi organisasi, kepemimpinan transformasional, dan keadilan organisasi terhadap Organizational Citizenship Behavior (OCB), serta bagaimana Organizational Citizenship Behavior (OCB) memberikan pengaruh terhadap kinerja dan komitmen organisasional PT. Yamaha Direct Distribution Sales Bali. Populasi penelitian ini adalah seluruh karyawan tetap yang bekerja di PT. Yamaha Direct Distribution Sales Bali yaitu sebanyak 37 orang. Teknik penentuan sampel yang digunakan pada penelitian ini adalah sampling jenuh atau sensus dengan instrumen penelitian menggunakan kuesioner. Data dianalisis menggunakan analisis SEM (Structural Equation Modelling) berbasis component atau variance yaitu PLS (Partial Least Square). Hasil penelitian menunjukkan bahwa komunikasi organisasi, kepemimpinan transformasional, dan keadilan organisasi berpengaruh positif dan signifikan terhadap Organizational Citizenship Behavior. Organizational Citizenship Behavior berpengaruh positif dan signifikan terhadap kinerja karyawan, dan Organizational Citizenship Behavior berpengaruh positif dan signifikan terhadap komitmen organisasional.
\end{abstract}

Kata Kunci: Komunikasi Organisasi, Kepemimpinan Transformasional, Keadilan Organisasi, Organizational Citizenship Behavior, Kinerja Karyawan, Komitmen Organisasional.

\begin{abstract}
This purpose research aims to analyze and explain the influence of organizational communication, transformational leadership, and organizational citizenship toward Organizational Behavior (OCB), and how Organizational Citizenship Behavior (OCB) has an effect on the performance and organizational commitment of PT. Yamaha Direct Distribution Sales Bali. The population of this research is all permanent employees who work in PT. Yamaha Direct Distribution Sales Bali as many as 37 people. Sample determination technique used in this research is saturated or census sampling with research instrument using questionnaire. Data were analyzed using SEM (Structural Equation Modeling) analysis based on component or variance that is PLS (Partial Least Square). The results showed that organizational communication, transformational leadership, and organizational justice had a positive and significant effect on Organizational Citizenship Behavior. Organizational Citizenship Behavior has a positive and significant impact on employee performance, and Organizational Citizenship Behavior has a positive and significant effect on organizational commitment of employees.
\end{abstract}

Keywords: Organizational Communication, Transformational Leadership, Organizational Justice, Organizational Citizenship Behavior, Employee Performance, Organizational Commitment of Employees. 
Meylinda Triyanthi, dan Made Subudi. Pengaruh Komunikasi Organisasi, Kepemimpin.....

\section{PENDAHULUAN}

Seluruh industri dan dunia usaha di Indonesia diharapkan mampu merealisasikan revolusi mental yang digaungkan Presiden Jokowi. Salah satu industri besar di Indonesia adalah PT. Yamaha Indonesia Motor Manufacturing dimana Yamaha memberikan kontribusi besar dalam penyediaan alat transportasi kendaraan roda dua, dengan standar kualitas yang tinggi disertai pelayanan purna jual yang tersebar diseluruh Indonesia dengan total jaringan lebih dari 3000 dealer dan bengkel yang tersebar di Indonesia.

Hal ini tentunya membutuhkan tenaga kerja Indonesia yang tidak sedikit jumlahnya. Para tenaga kerja ini diberikan ilmu dan pelatihan keterampilan yang sesuai dengan bidang pekerjaannya sehingga mampu bekerja secara optimal agar dapat mencapai visi, misi, dan tujuan PT. Yamaha Indonesia Motor Manufacturing. Dewasa ini, PT. Yamaha Indonesia Motor Manufacturing mengalami persaingan yang cukup ketat. Namun pada kenyataannya masalah yang dihadapi cukup kompleks untuk mencapai tujuan tersebut. Salah satunya terdapat pada kualitas tenaga kerja (SDM) yang masih rendah. Kondisi ini juga dialami oleh PT. Yamaha Direct Distribution Sales Bali di Kota Denpasar yang merupakan perwakilan PT. Yamaha Indonesia Motor Manufacturing. Selain untuk mengatur kebijakan dari sisi sales dan after sales dealer resmi Yamaha yang ada di Bali, PT. Yamaha Direct Distribution Sales Bali juga memiliki fungsi utama untuk mendistribusikan unit sepeda motor ke dealer resmi Yamaha, maka dalam pelaksanaanya diperlukan peran SDM yang merupakan salah satu aspek penting yang perlu dibenahi untuk mencapai kualitas tenaga kerja yang baik, agar dapat 
menunjang kinerja perusahaan secara optimal dan mencapai posisi teratas dalam penjualan sepeda motor di Bali.

Efektifnya peranan karyawan sangat ditentukan oleh perilaku organisasi dari perusahaan tersebut. Perilaku organisasi terkait dengan apa yang dilakukan oleh orang dalam organisasi dan bagaimana perilaku tersebut mempengaruhi kinerja organisasi. Perilaku organisasi mencakup komponen yang membentuk misalnya: motivasi, perilaku kekuasaan pemimpin, komunikasi interpersonal, struktural dan proses kelompok pembelajaran, pengembangan sikap dan persepsi, desain kerja, serta stress.

Dalam prosesnya, perilaku organisasi dilakukan dalam berbagai tingkatan, diantaranya individu (individual level), kelompok (group level), dan organisasi (organizational level). Terdapat beberapa faktor yang mempengaruhinya yaitu pengambilan keputusan dalam organisasi, komunikasi, kepemimpinan, struktur kelompok, keadilan organisasi, budaya organisasi, kebijakan SDM, serta kerjasama tim yang mampu meningkatkan produktivitas kerja karyawan dan perusahaan (Hadian dan Adang, 2010).

Organizational citizenship behavior menjadi salah satu bukti adanya kerjasama tim yang baik didalam sebuah perusahaan. Organizational citizenship behavior (OCB) adalah sikap membantu yang ditunjukkan oleh anggota organisasi, yang sifatnya konstruktif, dihargai oleh perusahaan tetapi tidak secara langsung berhubungan dengan produktivitas individu (Bateman \& Organ dalam Bhutto, 2012). Rohmah (2011) menjelaskan bahwa para anggota diharapkan selalu menciptakan komunikasi interpersonal yang berkualitas agar semakin 
Meylinda Triyanthi, dan Made Subudi. Pengaruh Komunikasi Organisasi, Kepemimpin.....

efektif hubungan yang terjadi diantara mereka, karena melalui komunikasi interpersonal yang efektif dan berkualitas dapat membentuk dan memperkuat sikap positif anggota sebagai bentuk dari organizational citizenship behavior. Perilaku organizational citizenship behavior karyawan juga dipengaruhi oleh faktor gaya kepemimpinan yang diterapkan dalam organisasi. Gaya kepemimpinan transformasional memiliki peranan yang penting bagi organisasi atau perusahaan.

Maysarah (2015) menyatakan bahwa keadilan organisasi secara nyata yang perlu perusahaan utamakan yaitu karyawan harus merasa bahwa mereka diperlakukan secara adil bahwa prosedur dan hasil adalah adil. Keadilan organisasi salah satunya berbentuk dukungan dari perusahaan yang mereka rasakan, dan selanjutnya mendorong mereka untuk membalas dengan perilaku extrarole (OCB).

Karyawan dengan organizational citizenship behavior yang tinggi akan meningkatkan produktivitas dan kesuksesan dirinya didalam suatu organisasi (Novelia, dkk. 2016). Hasil penelitian yang dilakukan oleh Darto (2014), Lestari dkk (2015) memperoleh hasil bahwa Organizational Citizenship Behavior (OCB) berpengaruh positif signifikan terhadap kinerja karyawan. Semakin tinggi organizational citizenship behavior, maka kinerja akan meningkat. Hasil penelitian yang dilakukan Kesuma dan Supartha (2016) menunjukkan hasil bahwa organizational citizenship behavior berpengaruh positif terhadap komitmen organisasional, artinya Organizational Citizenship Behavior memiliki keterkaitan erat, positif dengan komitmen organisasional. 
Adapun rumusan masalahnya sebagai berikut:

1) Bagaimana pengaruh komunikasi organisasi terhadap organizational citizenship behavior karyawan PT. Yamaha Direct Distribution Sales Bali ?

2) Bagaimana pengaruh kepemimpinan transformasional terhadap organizational citizenship behavior karyawan PT. Yamaha Direct Distribution Sales Bali?

3) Bagaimana pengaruh keadilan organisasi terhadap organizational citizenship behavior karyawan PT. Yamaha Direct Distribution Sales Bali?

4) Bagaimana pengaruh organizational citizenship behavior terhadap kinerja karyawan PT. Yamaha Direct Distribution Sales Bali?

5) Bagaimana pengaruh organizational citizenship behavior terhadap komitmen organisasional PT. Yamaha Direct Distribution Sales Bali?

Huang (2012) mengemukakan tiga kategori perilaku pekerja, yaitu: (1) berpartisipasi, terikat dan berada dalam suatu organisasi; (2) harus menyelesaikan suatu pekerjaan dan bertindak sesuai dengan prinsip-prinsip yang diatur oleh organisasi; serta (3) melakukan aktivitas yang inovatif dan spontan melebihi persepsi perannya dalam organisasi. Kategori terakhirlah yang sering disebut sebagai Organizational Citizenship Behavior (OCB) atau the extra-role behavior (Huang, 2012). Robbins dan Judge (2008:40) mendefinisikan OCB sebagai perilaku pilihan yang tidak menjadi bagian dari kewajiban kerja formal seorang karyawan, namun mendukung berfungsinya organisasi tersebut secara efektif. Shweta dan Srirang (2009) menyatakan bahwa OCB ditandai dengan usaha dalam bentuk apapun yang dilakukan berdasarkan kebijaksanaan karyawan yang 
Meylinda Triyanthi, dan Made Subudi. Pengaruh Komunikasi Organisasi, Kepemimpin.....

memberikan manfaat bagi organisasi tanpa mengharapkan imbalan apapun. Kumar et al. (2009) mendefinisikan OCB sebagai perilaku individu yang memberikan kontribusi pada terciptanya efektifitas organisasi dan tidak berkaitan langsung.

Employee communication merupakan salah satu bentuk dari aktivitas internal public relations, maka berkaitan dengan itu Frank Jefkins (1994) mengatakan bahwa, "internal public relations is therefore one of the keys to successful management, requiring open management and closing the gap between the two sides", berarti bahwa, internal public relations menjadi salah satu kunci menuju manajemen sukses, menuntut pengelolaan terbuka dan menutup celah antara manajemen dan karyawan. Penelitian yang dilakukan oleh Rohmah (2011), menyatakan bahwa komunikasi interpersonal berpengaruh positif dan signifikan terhadap Organizational Citizenship Behavior (OCB). Hasil serupa juga diperoleh Amanda (2014) yang mendapatkan hasil penelitian yaitu terdapat pengaruh positif employee communication terhadap Organizational Citizenship Behavior.

Gaya kepemimpinan transformasional memiliki peranan yang penting bagi organisasi atau perusahaan. Penelitian yang dilakukan oleh Supit (2016) mendapatkan hasil bahwa kepemimpinan transformasional berpengaruh signifikan terhadap OCB. Prahesti (2016) mendapatkan hasil bahwa kepemimpinan transformasional berpengaruh positif dan signifikan terhadap Organizational Citizenship Behavior, Manajer harus mampu menerapkan gaya kepemimpinan transformasional dengan optimal agar karyawan mau memberikan $O C B$ yang tinggi sehingga dapat meningkatkan kinerja karyawan koperasi di Tabanan. 
Sejumlah studi menunjukkan adanya hubungan yang kuat antara keadilan organisasi dan OCB. Keadilan organisasi secara nyata yang perlu perusahaan utamakan yaitu karyawan harus merasa bahwa mereka diperlakukan secara adil bahwa prosedur dan hasil adalah adil. Maysarah (2015) mendapatkan hasil penelitian yaitu budaya organisasi, keadilan organisasi, dan komitmen organisasional berpengaruh positif dan signifikan terhadap Organizational Citizenship Behavior PT Kereta Api Indonesia (Persero) Daerah Operasi 4 Semarang baik secara parsial maupun secara simultan. Sani (2013) juga memperoleh hasil yaitu keadilan prosedural dan komitmen organisasi berpengaruh secara positif terhadap Organizational Citizenship Behavior. Penelitian serupa oleh Tahseen and Akhtar (2016), Awang and Ahmad (2015), Chen and Jin (2014), serta Guh et al. (2013) memperoleh hasil bahwa keadilan organisasi berpengaruh secara signifikan terhadap organizational citizenship behavior.

Kinerja karyawan merupakan hasil kerja secara kualitas dan kuantitas yang telah dicapai oleh seseorang karyawan dalam melaksanakan tugasnya sesuai dengan tanggung jawab yang diberikan kepadanya (Mangkunegara, 2006:9). Setiap organisasi maupun perusahaan akan berusaha untuk meningkatkan kinerja karyawan untuk mencapai tujuan organisasi yang telah ditetapkan. Penelitian yang dilakukan Lestari, dkk. (2015) memperoleh hasil bahwa Organizational Citizenship Behavior (OCB) berpengaruh signifikan terhadap kinerja karyawan. Damaryanthi dan Dewi (2016) mendapatkan hasil penelitian yaitu Organizational Citizenship Behavior berpengaruh positif dan signifikan terhadap kinerja 
Meylinda Triyanthi, dan Made Subudi. Pengaruh Komunikasi Organisasi, Kepemimpin.....

karyawan. Artinya, apabila Organizational Citizenship Behavior meningkat, maka kinerja karyawan akan mengalami peningkatan juga.

Komitmen organisasional merupakan tingkat sejauh mana seorang karyawan memihak pada suatu organisasi tertentu dan tujuan-tujuannya, serta berniat untuk mempertahankan keanggotaannya dalam organisasi itu. Komitmen organisasional dapat dipengaruhi oleh berbagai faktor, diantaranya adalah perilaku karyawan. Salah satu perilaku yang dapat mempengaruhi komitmen organisasional adalah perilaku kemasyarakatan organisasional atau Organizational Citizenship Behavior (OCB). Penelitian yang dilakukan oleh Kesuma dan Supartha (2016) menunjukkan hasil bahwa OCB berpengaruh positif terhadap komitmen organisasional, artinya Organizational Citizenship Behavior memiliki keterkaitan erat, positif dengan komitmen organisasional.

Berdasarkan paparan teori dan penelitian terdahulu maka kerangka konsep hipotesis yang dapat di susun dalam Gambar 1. adalah sebagai berikut:

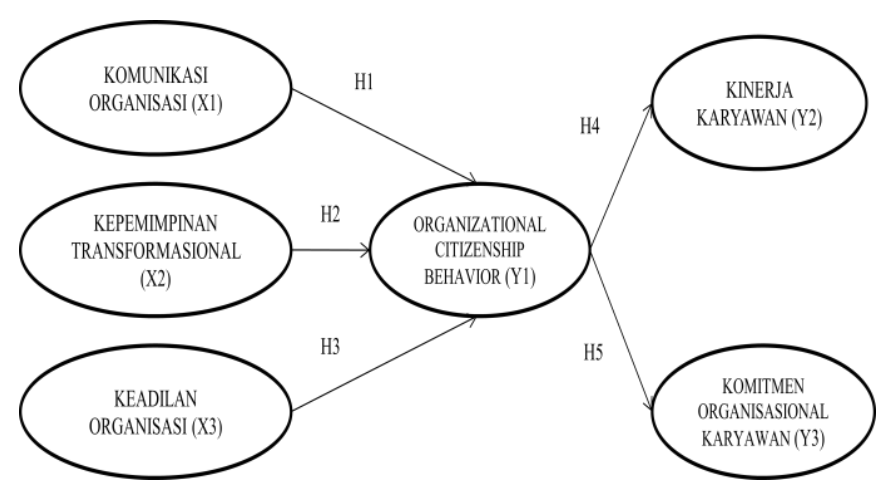

Gambar 1. Model Kerangka Konsep 


\section{METODE PENELITIAN}

\section{Jenis dan Sumber Data}

Data yang digunakan adalah data kuantitatif dan kualitatif. Data kuantitatif yang diperoleh seperti data penjualan PT. Yamaha Direct Distribution Sales di Bali Periode 2013-2016, data jumlah karyawan dan data dari kuesioner berupa jumlah responden dan skor total masing - masing variabel. Sedangkan data kualitatif dalam penelitian ini adalah gambaran umum perusahaan dan hasil riset awal yang dilakukan melalui wawancara pada karyawan PT. Yamaha Direct Distribution Sales Bali di Kota Denpasar.

Data primer berasal dari karyawan yang menjadi responden penelitian ini dengan mengisi kuesioner untuk mengetahui tentang persepsi mereka terkait variabel yang diteliti dan hasil riset awal melalui wawancara terkait faktor-faktor internal organisasi, khususnya mengenai komunikasi organisasi, kepemimpinan transformasional, dan keadilan organisasi yang memengaruhi organizational citizenship behavior serta dampaknya terhadap kinerja karyawan dan komitmen organisasional. Sedangkan data sekunder dalam penelitian ini diperoleh dari PT. Yamaha Direct Distribution Sales Bali di Kota Denpasar.

\section{Variabel Penelitian}

1) Konstruk eksogen

Konstruk eksogen: komunikasi organisasi $\left(\mathrm{X}_{1}\right)$, kepemimpinan transformasional $\left(\mathrm{X}_{2}\right)$, dan keadilan organisasi $\left(\mathrm{X}_{3}\right)$.

2) Konstruk endogen 
Meylinda Triyanthi, dan Made Subudi. Pengaruh Komunikasi Organisasi, Kepemimpin.....

Konstruk endogen: organizational citizenship behavior $\left(\mathrm{Y}_{1}\right)$, kinerja karyawan $\left(\mathrm{Y}_{2}\right)$, dan komitmen organisasional $\left(\mathrm{Y}_{3}\right)$.

\section{Populasi dan Sampel}

Populasi penelitian ini adalah seluruh karyawan tetap yang bekerja di PT. Yamaha Direct Distribution Sales Bali yaitu sebanyak 37 orang yang terdaftar dalam Tabel 1. berikut ini:

Tabel 1.

Karyawan Tetap PT. Yamaha Direct Distribution Sales Bali yang Menjadi Sampel Penelitian

\begin{tabular}{clc}
\hline No. & \multicolumn{1}{c}{ Divisi } & $\begin{array}{c}\text { Jumlah Karyawan } \\
\text { (Orang) }\end{array}$ \\
\hline 1 & Chief PT. Yamaha Direct Distribution Sales Bali & 1 \\
2 & Coordinator Administration & 1 \\
3 & Sales Administration & 1 \\
4 & Area Marketing Development & 5 \\
5 & Invoice Officer & 1 \\
6 & Finance Administration & 2 \\
7 & Promotion Divition & 2 \\
8 & Service Divition & 5 \\
9 & Spare Parts & 1 \\
10 & Yamaha Academy Training & 1 \\
11 & Call Centre Flagship Shop & 2 \\
12 & Yamaha Academy \& Area Service Development & 1 \\
13 & Coordinator Customer Satisfaction & 3 \\
14 & General Administration & 1 \\
15 & Information Technology & 1 \\
16 & Guest Relationship Officer (Flagship Shop) & 1 \\
17 & Service Advisor (Flagship Shop) & 2 \\
18 & Supervisor Depo Bali (Warehouse Divition) & 1 \\
19 & Staff Depo Bali (Warehouse Divition) & 57 \\
& & Jumlah
\end{tabular}

Sumber: PT. Yamaha Direct Distribution Sales Bali

\section{Metode Pengumpulan Data}

Penelitian ini dilakukan dengan menggunakan cross sectional survey, yaitu metode pengumpulan data dimana informasi dikumpulkan hanya pada saat 
tertentu. Sedangkan teknik pengumpulan data yang digunakan adalah sebagai berikut:

1) Wawancara, digunakan untuk memperoleh informasi mengenai isu yang diteiliti yaitu Organizational Citizenship Behavior (OCB).

2) Kuesioner, digunakan untuk memperoleh data primer kuantitatif penelitian mengenai variabel-variabel yang diteliti. Data dikumpulkan dengan mengirimkan kuesioner yang diberikan secara pribadi. Setelah kuesioner didistribusikan, responden diberi waktu selama satu minggu untuk menjawab, dan setelah selesai mengisi kuesioner tersebut akan dikumpulkan kembali.

\section{Teknik Analisis Data}

Penelitian ini menggunakan statistik deskriptif dan statistik inferensial untuk analisis data. Statistik deskriptif digunakan untuk mendeskripsikan data demografis responden yang disajikan melalui tabel, perhitungan rata-rata, dan perhitungan persentase, sedangkan statistik inferensial digunakan untuk menguji hipotesis. Penelitian ini menggunakan analisis SEM (Structural Equation Modelling) berbasis component atau variance yaitu PLS (Partial Least Square).

\section{HASIL DAN PEMBAHASAN}

\section{Karakteristik Responden}

Penelitian ini menggunakan sampel jenuh yang dimana seluruh populasi menjadi sampel, sehingga 37 karyawan PT. Yamaha Direct Distribution Sales Bali menjadi responden penelitian. Namun pada penelitian ini hanya 34 karyawan PT. Yamaha Direct Distribution Sales Bali yang dapat mengisi kuisioner, dari 37 
Meylinda Triyanthi, dan Made Subudi. Pengaruh Komunikasi Organisasi, Kepemimpin.....

kuesioner yang telah disebarkan terdapat 3 lembar yang tidak terisi dikarenakan responden yang bersangkutan tidak berada di tempat. Berikut data identitas responden berdasarkan jenis kelamin, usia, pendidikan terakhir dan lama bekerja. Secara rinci karakteristik responden disajikan pada Tabel 2.

Tabel 2.

Karakteristik Responden

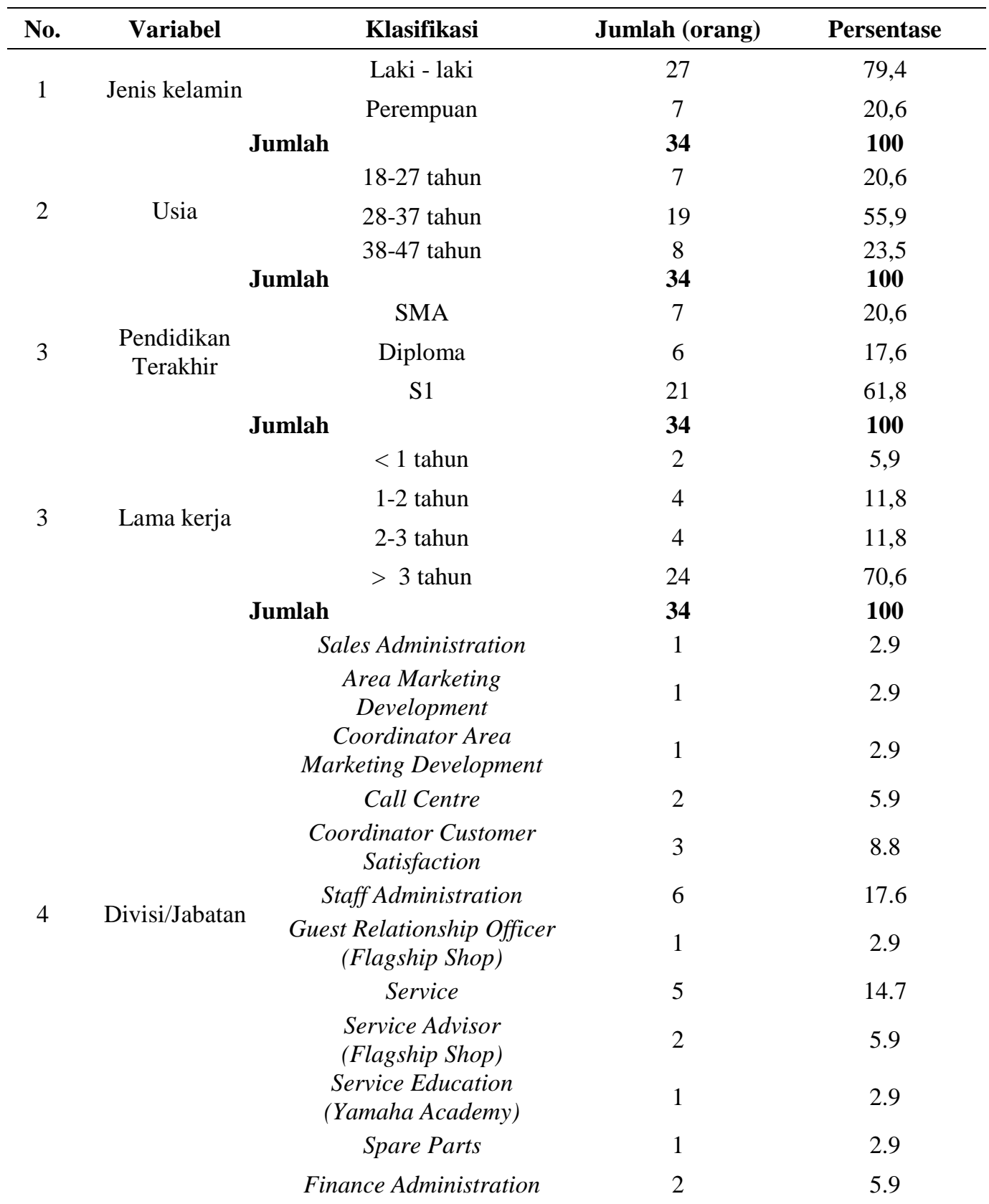




\begin{tabular}{ccc} 
Marketing Divition & 5 & 14.7 \\
Promotion Divition & 2 & 5.9 \\
Information Technology & 1 & 2.9 \\
Jumlah & $\mathbf{3 4}$ & $\mathbf{1 0 0}$ \\
\hline
\end{tabular}
Sumber: Data primer, 2017

Karakteristik responden yang disajikan pada Tabel 2. menunjukkan bahwa dari 15 divisi jabatan yang ada pada PT. Yamaha Direct Distribution Sales Bali yang menjadi responden, didominasi oleh laki-laki sebanyak 79,4 persen, sedangkan sisanya perempuan sebesar 20,6 persen dengan rentang usia dominan antara 28-37 tahun, memiliki pendidikan tertinggi pada tingkat Sarjana (S1) dan 70,6 persen memiliki masa kerja > 3 tahun.

\section{Deskripsi Variabel Penelitian}

Penilaian distribusi data setiap variabel menggunakan rentang kriteria yang dihitung dengan persamaan:

$$
\begin{aligned}
\text { Nilai Interval } & =\frac{(\text { Nilai batas tertinggi }- \text { nilai batas terendah })}{\text { Total nilai yang digunakan }} \\
& =\frac{(5-1)}{5}=0,8
\end{aligned}
$$

Berdasarkan hasil interval range maka dapat disusun kriteria hasil pengukuran konstruk dalam Tabel 3. sebagai berikut:

Tabel 3.

\begin{tabular}{|c|c|c|c|c|c|c|}
\hline $\begin{array}{l}\text { Nilai } \\
\text { Skor }\end{array}$ & $\begin{array}{c}\text { Komunikasi } \\
\text { Organisasi }\end{array}$ & $\begin{array}{c}\text { Kepemimpinan } \\
\text { Transformasional }\end{array}$ & $\begin{array}{c}\text { Kinerja } \\
\text { Karyawan }\end{array}$ & $\begin{array}{c}\text { Keadilan } \\
\text { Organisasi }\end{array}$ & $O C B$ & $\begin{array}{c}\text { Komitmen } \\
\text { Organisasional }\end{array}$ \\
\hline $\begin{array}{c}1,00- \\
1,80\end{array}$ & & Sangat Buruk & & $\begin{array}{c}\text { Sangat tidak } \\
\text { adil }\end{array}$ & & Sangat rendah \\
\hline $\begin{array}{c}1,81- \\
2,61\end{array}$ & & Buruk & & Tidak adil & & Rendah \\
\hline $\begin{array}{c}2,62- \\
3,42\end{array}$ & & Sedang & & Cukup & & Cukup \\
\hline $\begin{array}{c}3,43- \\
4,23\end{array}$ & & Baik & & Adil & & Tinggi \\
\hline $\begin{array}{c}4,24- \\
5,00\end{array}$ & & Sangat baik & & Sangat adil & & Sangat Tinggi \\
\hline
\end{tabular}

Rangkuman Interval Skor Variabel Penelitian 
Meylinda Triyanthi, dan Made Subudi. Pengaruh Komunikasi Organisasi, Kepemimpin.....

Kriteria pengukuran tersebut menunjukkan bahwa semakin tinggi nilai rata-rata yang diperoleh menunjukkan semakin baik tanggapan responden terhadap item maupun variabel tersebut.

\section{Deskripsi Penilaian Responden Terhadap Indikator Variabel Komunikasi Organisasi}

Data yang ditunjukan Tabel 4. menampilkan proporsi jawaban responden, rata-rata jawaban, dan kriteria penilaian jawaban responden untuk masing-masing pernyataan pada variabel komunikasi organisasi.

Tabel 4.

Deskripsi Penilaian Responden Terhadap Indikator Variabel Komunikasi Organisasi

\begin{tabular}{|c|c|c|c|c|c|c|c|}
\hline \multirow{2}{*}{ Pernyataan } & \multicolumn{5}{|c|}{ Frekuensi Jawaban Responden } & \multirow{2}{*}{$\begin{array}{c}\text { Rata- } \\
\text { rata }\end{array}$} & \multirow{2}{*}{ Keterangan } \\
\hline & 1 & 2 & 3 & 4 & 5 & & \\
\hline Berkoordinasi dengan & & & & & & & \\
\hline $\begin{array}{l}\text { karyawan lain untuk } \\
\text { menyelesaikan } \\
\text { pemasalahan }\left(\mathrm{X}_{1.1}\right)\end{array}$ & 0 & 0 & 3 & 13 & 18 & 4,44 & Sangat Baik \\
\hline $\begin{array}{l}\text { Berdiskusi dengan } \\
\text { pimpinan mengenai } \\
\text { masalah perkerjaan }\left(\mathrm{X}_{1.2}\right)\end{array}$ & 0 & 0 & 5 & 19 & 10 & 4,15 & Baik \\
\hline $\begin{array}{l}\text { Tugas yang diberikan } \\
\text { pimpinan sesuai dengan } \\
\text { kemampuan yang dimiliki } \\
\left(\mathrm{X}_{1.3}\right)\end{array}$ & 0 & 1 & 7 & 24 & 2 & 3,79 & Baik \\
\hline $\begin{array}{l}\text { Informasi yang diberikan } \\
\text { pimpinan jelas }\left(\mathrm{X}_{1.4}\right)\end{array}$ & 0 & 1 & 5 & 22 & 6 & 3,97 & Baik \\
\hline \multicolumn{6}{|c|}{$\begin{array}{r}\text { Rata-rata Variabel Komunikasi Organisasi } \\
\text { Res }\end{array}$} & 4,08 & Baik \\
\hline
\end{tabular}

Sumber: Data primer diolah, 2017

Hasil analisis deksriptif sebagaimana disajikan pada tabel 4. menunjukan bahwa variabel komunikasi organisasi secara keseluruhan memperoleh nilai ratarata sebesar 4,08, yang berarti bahwa karyawan di PT. Yamaha Direct Distribution Sales Bali memiliki komunikasi organisasi yang baik. Pencapaian nilai rata-rata diikuti oleh adanya indikator yang lebih tinggi dan lebih rendah dari rata-rata variabel komunikasi organisasi. Dari 4 indikator yang digunakan untuk mengukur komunikasi organisasi, maka terdapat 2 indikator yang nilainya berada 
di atas nilai rata-rata $(4,08)$ variabel komunikasi organisasi yaitu komunikasi dengan rekan kerja dan komunikasi dengan manajer. Indikator komunikasi dengan rekan kerja memiliki nilai paling tinggi jika dibandingkan dengan indikator lainnya. Hal tersebut disebabkan karena karyawan PT. Yamaha Direct Distribution Sales Bali sudah saling berkoordinasi dengan rekan kerja dalam menyelesaikan permasalahan yang dihadapi.

\section{Deskripsi Penilaian Responden Terhadap Indikator Variabel Kepemimpinan Transformasional}

Data yang ditunjukan Tabel 5. menampilkan proporsi jawaban responden, rata-rata jawaban, dan kriteria penilaian jawaban responden untuk masing-masing pernyataan pada variabel kepemimpinan transformasional.

Tabel 5.

Deskripsi Penilaian Responden Terhadap Indikator Variabel Kepemimpinan Transformasional

\begin{tabular}{|c|c|c|c|c|c|c|c|}
\hline \multirow{2}{*}{ Pernyataan } & \multicolumn{5}{|c|}{ Frekuensi Jawaban Responden } & \multirow{2}{*}{ Rata-rata } & \multirow{2}{*}{ Keterangan } \\
\hline & 1 & 2 & 3 & 4 & 5 & & \\
\hline $\begin{array}{l}\text { Pimpinan selalu } \\
\text { memberikan kepercayaan } \\
\text { penuh }\left(\mathrm{X}_{2.1}\right)\end{array}$ & 0 & 1 & 9 & 21 & 3 & 3,76 & Baik \\
\hline $\begin{array}{l}\text { Pimpinan memiliki } \\
\text { kreativitas yang tinggi }\left(\mathrm{X}_{2.2}\right)\end{array}$ & 0 & 1 & 5 & 22 & 6 & 3,97 & Baik \\
\hline $\begin{array}{l}\text { Pimpinan selalu } \\
\text { memberikan motivasi } \\
\text { kepada bawahan. }\left(\mathrm{X}_{2.3}\right)\end{array}$ & 0 & 1 & 2 & 20 & 11 & 4,21 & Baik \\
\hline $\begin{array}{l}\text { Pimpinan selalu } \\
\text { memberikan perhatian } \\
\text { dalam pengembangan karir } \\
\text { karyawann }\left(\mathrm{X}_{2.4}\right)\end{array}$ & 0 & 1 & 10 & 16 & 7 & 3,85 & Baik \\
\hline Rata-rata Variabel Ke & min & 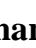 & ans & 1asi & & 3,95 & Baik \\
\hline
\end{tabular}

Sumber: Data primer diolah, 2017

Hasil analisis deksriptif sebagaimana disajikan pada tabel 6. menunjukkan skor rata-rata kepemimpinan transformasional sebesar 3,95, yang berarti bahwa tingkat kepemimpinan transformasional di PT. Yamaha Direct Distribution Sales Bali dikatakan baik. Pencapaian nilai rata-rata diikuti oleh adanya indikator yang 
Meylinda Triyanthi, dan Made Subudi. Pengaruh Komunikasi Organisasi, Kepemimpin.....

lebih tinggi dan lebih rendah dari rata-rata variabel kepemimpinan transformasional. Dari 4 indikator yang digunakan untuk mengukur kepemimpinan transformasional, maka terdapat 2 indikator yang nilainya berada di atas nilai rata-rata $(3,95)$ variabel kepemimpinan transformasional yaitu indikator stimulasi intelektual dan motivasi. Indikator motivasi memiliki nilai paling tinggi jika dibandingkan dengan indikator lainnya. Hal tersebut disebabkan karena karyawan PT. Yamaha Direct Distribution Sales Bali selalu mendapatkan motivasi yang baik dari pimpinan.

\section{Deskripsi Penilaian Responden Terhadap Indikator Variabel Keadilan Organisasi}

Data yang ditunjukan Tabel 6. menampilkan proporsi jawaban responden, rata-rata jawaban, dan kriteria penilaian jawaban responden untuk masing-masing pernyataan pada variabel keadilan organisasi.

Tabel 6.

Deskripsi Penilaian Responden Terhadap Indikator Variabel Keadilan Organisasi

\begin{tabular}{|c|c|c|c|c|c|c|c|}
\hline \multirow{2}{*}{ Pernyataan } & \multicolumn{5}{|c|}{ Frekuensi Jawaban Responden } & \multirow{2}{*}{$\begin{array}{c}\text { Rata- } \\
\text { rata }\end{array}$} & \multirow{2}{*}{ Keterangan } \\
\hline & 1 & 2 & 3 & 4 & 5 & & \\
\hline $\begin{array}{l}\text { Pimpinan selalu } \\
\text { mempertimbangkan hak-hak } \\
\text { karyawan }\left(\mathrm{X}_{3.1}\right)\end{array}$ & 0 & 2 & 9 & 19 & 4 & 3,74 & Adil \\
\hline $\begin{array}{l}\text { Pimpinan berusaha } \\
\text { mendengarkan pendapat } \\
\text { karyawan }\left(\mathrm{X}_{3.2}\right)\end{array}$ & 1 & 2 & 11 & 20 & 0 & 3,47 & Adil \\
\hline $\begin{array}{l}\text { Pimpinan memberikan jadwal } \\
\text { kerja secara adil kepada } \\
\text { seluruh karyawan }\left(\mathrm{X}_{3.3}\right)\end{array}$ & 0 & 3 & 7 & 19 & 5 & 3,76 & Adil \\
\hline \multicolumn{6}{|c|}{$\begin{array}{r}\text { Rata-rata Variabel Keadilan Organisasi } \\
\text { Rata }\end{array}$} & 3,65 & Adil \\
\hline
\end{tabular}

Sumber: Data primer diolah, 2017

Hasil analisis deksriptif sebagaimana disajikan pada tabel 6. menunjukkan skor rata-rata keadilan organisasi sebesar 3,65, yang berarti bahwa tingkat keadilan organisasi di PT. Yamaha Direct Distribution Sales Bali dikatakan adil. 
Pencapaian nilai rata-rata diikuti oleh adanya indikator yang lebih tinggi dan lebih rendah dari rata-rata variabel keadilan organisasi. Dari 3 indikator yang digunakan untuk mengukur keadilan organisasi, maka terdapat 2 indikator yang nilainya berada di atas nilai rata-rata $(3,65)$ variabel keadilan organisasi yaitu indikator keadilan interaksional dan keadilan distributif. Indikator keadilan distributif dan keadilan interaksional memiliki nilai paling tinggi jika dibandingkan dengan indikator lainnya. Hal tersebut disebabkan karena karyawan PT. Yamaha Direct Distribution Sales Bali sudah memperoleh jadwal kerja yang adil dari organisasi.

\section{Deskripsi Penilaian Responden Terhadap Indikator Variabel Organizational Citizenship Behavior}

Data yang ditunjukan Tabel 7. menampilkan proporsi jawaban responden, rata-rata jawaban, dan kriteria penilaian jawaban responden untuk masing-masing pernyataan pada variabel organizational citizenship behavior.

Tabel 7.

Deskripsi Penilaian Responden Terhadap Indikator Variabel Organizational Citizenship Behavior

\begin{tabular}{|c|c|c|c|c|c|c|c|}
\hline \multirow[t]{2}{*}{ Pernyataan } & \multicolumn{5}{|c|}{$\begin{array}{c}\text { Frekuensi Jawaban } \\
\text { Responden }\end{array}$} & \multirow{2}{*}{$\begin{array}{l}\text { Rata- } \\
\text { rata }\end{array}$} & \multirow[t]{2}{*}{ Keterangan } \\
\hline & 1 & 2 & 3 & 4 & 5 & & \\
\hline $\begin{array}{l}\text { Bersedia menolong rekan kerja yang } \\
\text { mengalami kesulitan }\left(\mathrm{Y}_{1.1}\right)\end{array}$ & 0 & 0 & 1 & 21 & 12 & 4,32 & $\begin{array}{l}\text { Sangat } \\
\text { Tinggi }\end{array}$ \\
\hline $\begin{array}{l}\text { Sukarela melakukan sesuatu yang } \\
\text { bermanfaat bagi perusahaan. }\left(\mathrm{Y}_{1.2}\right)\end{array}$ & 0 & 1 & 6 & 22 & 5 & 3,91 & Tinggi \\
\hline $\begin{array}{l}\text { Selalu menjaga hubungan baik } \\
\text { dengan rekan kerja }\left(\mathrm{Y}_{1.3}\right)\end{array}$ & 0 & 0 & 3 & 20 & 11 & 4,24 & $\begin{array}{l}\text { Sangat } \\
\text { Tinggi }\end{array}$ \\
\hline $\begin{array}{l}\text { Selalu berpartisipasi dalam berbagai } \\
\text { kegiatan yang diselenggarakan oleh } \\
\text { perusahaan }\left(\mathrm{Y}_{1.4}\right)\end{array}$ & 0 & 0 & 7 & 22 & 5 & 3,94 & Tinggi \\
\hline $\begin{array}{l}\text { Menerima setiap kebijakan yang } \\
\text { ditetapkan oleh perusahaan }\left(\mathrm{Y}_{1.5}\right)\end{array}$ & 0 & 0 & 4 & 23 & 7 & 4,09 & gi \\
\hline \multicolumn{6}{|c|}{ Rata-rata Variabel organizational citizenship behavior. } & 4,10 & Tinggi \\
\hline
\end{tabular}

Sumber: Data primer diolah, 2017

Hasil analisis deksriptif sebagaimana disajikan pada tabel 7. menunjukkan skor rata-rata organizational citizenship behavior sebesar 4,10, yang berarti 
Meylinda Triyanthi, dan Made Subudi. Pengaruh Komunikasi Organisasi, Kepemimpin.....

bahwa tingkat organizational citizenship behavior karyawan PT. Yamaha Direct Distribution Sales Bali dikatakan tinggi. Pencapaian nilai rata-rata diikuti oleh adanya indikator yang lebih tinggi dan lebih rendah dari rata-rata variabel organizational citizenship behavior. Dari 5 indikator yang digunakan untuk mengukur organizational citizenship behavior, maka terdapat 2 indikator yang nilainya berada di atas nilai rata-rata $(4,10)$ variabel organizational citizenship behavior yaitu indikator altruism (membantu orang lain) dan courtesy (kebaikan). Indikator altruism (membantu orang lain) memiliki nilai paling tinggi jika dibandingkan dengan indikator lainnya. Hal tersebut disebabkan karena karyawan PT. Yamaha Direct Distribution Sales Bali bersedia menolong satu sama lain jika mengalami keusulitan dalam menyelesaikan pekerjaan.

\section{Deskripsi Penilaian Responden Terhadap Indikator Variabel Kinerja}

Data yang ditunjukan Tabel 8. menampilkan proporsi jawaban responden, rata-rata jawaban, dan kriteria penilaian jawaban responden untuk masing-masing pernyataan pada variabel kinerja karyawan.

Tabel 8.

Deskripsi Penilaian Responden Terhadap Indikator Variabel Kinerja

\begin{tabular}{|c|c|c|c|c|c|c|c|}
\hline \multirow{2}{*}{ Pernyataan } & \multicolumn{5}{|c|}{ Frekuensi Jawaban Responden } & \multirow{2}{*}{$\begin{array}{c}\text { Rata- } \\
\text { rata }\end{array}$} & \multirow{2}{*}{ Keterangan } \\
\hline & 1 & 2 & 3 & 4 & 5 & & \\
\hline $\begin{array}{l}\text { Menyelesaikan tugas sesuai } \\
\text { harapan. }\left(\mathrm{Y}_{2.1}\right)\end{array}$ & 0 & 0 & 4 & 18 & 12 & 4,24 & Sangat Baik \\
\hline $\begin{array}{l}\text { Menggunakan waktu seefektif } \\
\text { mungkin }\left(\mathrm{Y}_{2.2}\right)\end{array}$ & 0 & 0 & 5 & 21 & 8 & 4,09 & Baik \\
\hline $\begin{array}{l}\text { Berusaha memaksimalkan } \\
\text { tingkat kehadiran }\left(\mathrm{Y}_{2.3}\right)\end{array}$ & 0 & 0 & 1 & 22 & 11 & 4,29 & Sangat Baik \\
\hline $\begin{array}{l}\text { Memberikan pelayanan yang } \\
\text { terbaik }\left(\mathrm{Y}_{2.4}\right)\end{array}$ & 0 & 0 & 1 & 14 & 19 & 4,53 & Sangat Baik \\
\hline $\begin{array}{l}\text { Menyelesaikan pekerjaan tepat } \\
\text { pada waktunya }\left(\mathrm{Y}_{2.5}\right)\end{array}$ & 0 & 0 & 5 & 22 & 7 & 4,06 & Baik \\
\hline \multicolumn{6}{|c|}{ Rata-rata Variabel Kinerja Karyawan } & 4,24 & Sangat Baik \\
\hline
\end{tabular}
Sumber: Data primer diolah, 2017 
Hasil analisis deksriptif sebagaimana disajikan pada tabel 8. menunjukkan skor rata-rata kinerja karyawan sebesar 4,24, yang berarti bahwa kinerja karyawan PT. Yamaha Direct Distribution Sales Bali sudah baik. Pencapaian nilai rata-rata diikuti oleh adanya indikator yang lebih tinggi dan lebih rendah dari rata-rata variabel kinerja karyawan. Dari 5 indikator yang digunakan untuk mengukur kinerja karyawan, maka terdapat 2 indikator yang nilainya berada di atas nilai rata-rata $(4,24)$ variabel kinerja karyawan yaitu indikator efficiency of work completed (efisiensi pekerjaan yang telah diselesaikan) dan presences at work (tingkat kehadiran) memiliki nilai paling tinggi jika dibandingkan dengan indikator lainnya. Hal tersebut disebabkan karena karyawan PT. Yamaha Direct Distribution Sales Bali selalu berusaha memberikan pelayanan yang terbaik kepada setiap pelanggan agar tujuan perusahaan tercapai.

\section{Deskripsi Penilaian Responden Terhadap Indikator Variabel Komitmen Organisasional}

Data yang ditunjukan Tabel 9. menampilkan proporsi jawaban responden, rata-rata jawaban, dan kriteria penilaian jawaban responden untuk masing-masing pernyataan pada variabel komitmen organisasional.

Tabel 9.

Deskripsi Penilaian Responden Terhadap Indikator Variabel Komitmen Organisasional

\begin{tabular}{|c|c|c|c|c|c|c|c|}
\hline \multirow[t]{2}{*}{ Pernyataan } & \multicolumn{5}{|c|}{$\begin{array}{l}\text { Frekuensi Jawaban } \\
\text { Responden }\end{array}$} & \multirow{2}{*}{$\begin{array}{c}\text { Rata- } \\
\text { rata }\end{array}$} & \multirow[t]{2}{*}{ Keterangan } \\
\hline & 1 & 2 & 3 & 4 & 5 & & \\
\hline $\begin{array}{l}\text { Terkait secara emosional } \\
\text { dengan tempat saya bekerja } \\
\left(\mathrm{Y}_{3.1}\right)\end{array}$ & 0 & 1 & 5 & 21 & 7 & 4,00 & Tinggi \\
\hline $\begin{array}{l}\text { Merasa rugi jika meninggalkan } \\
\text { tempat kerja }\left(\mathrm{Y}_{3.2}\right)\end{array}$ & 0 & 1 & 7 & 15 & 11 & 4,06 & Tinggi \\
\hline $\begin{array}{l}\text { Tetap bekerja dalam organisasi } \\
\text { merupakan kewajiban moral } \\
\left(\mathrm{Y}_{3.3}\right)\end{array}$ & 0 & 1 & 8 & 18 & 7 & 3,91 & Tinggi \\
\hline Rata-rata Variabel & mit & 71 & 101 & onal & & 3,99 & Tinggi \\
\hline
\end{tabular}


Meylinda Triyanthi, dan Made Subudi. Pengaruh Komunikasi Organisasi, Kepemimpin.....

Sumber: Data primer diolah, 2017

Hasil analisis deksriptif sebagaimana disajikan pada Tabel 9. menunjukkan skor rata-rata komitmen organisasional karyawan sebesar 3,99, yang berarti bahwa tingkat komitmen organisasional karyawan PT. Yamaha Direct Distribution Sales Bali dikatakan tinggi. Pencapaian nilai rata-rata diikuti oleh adanya indikator yang lebih tinggi dan lebih rendah dari rata-rata variabel komitmen organisasional karyawan. Dari 3 indikator yang digunakan untuk mengukur komitmen organisasional karyawan, maka terdapat 2 indikator yang nilainya berada di atas nilai rata-rata $(3,99)$ variabel komitmen organisasional karyawan yaitu indikator komitmen afektif dan komitmen kelanjutan. Indikator komitmen kelanjutan memiliki nilai paling tinggi jika dibandingkan dengan indikator lainnya. Hal tersebut disebabkan karena karyawan PT. Yamaha Direct Distribution Sales Bali sudah mempunyai komitmen yang tinggi, karena apabila karyawan meninggalkan tempatnya bekerja, mereka akan merasa rugi atau sia-sia.

\section{Evaluasi model pengukuran atau outer model}

\section{Convergent validity}

Convergent validity dengan indikator refleksif dapat dilihat dari korelasi antara skor indikator dengan skor variabelnya. Indikator individu dianggap reliabel apabila memiliki nilai korelasi diatas 0,50 . Hasil korelasi antara dimensi dengan variabelnya dapat dilihat pada Tabel 10. berikut. 
Tabel 10.

Hasil Pengujian Convergent Validity

\begin{tabular}{|c|c|c|}
\hline Variabel & Indikator & $\begin{array}{c}\text { Outer } \\
\text { Loadings }\end{array}$ \\
\hline \multirow{4}{*}{$\begin{array}{l}\text { Komunikasi } \\
\text { organisasi }\left(\mathrm{X}_{1}\right)\end{array}$} & $\begin{array}{l}\text { Saya selalu berkoordinasi dengan karyawan lain untuk menyelesaikan } \\
\text { pemasalahan }\left(\mathrm{X}_{1.1}\right)\end{array}$ & 0,791 \\
\hline & $\begin{array}{l}\text { Saya selalu berdiskusi dengan pimpinan mengenai masalah perkerjaan } \\
\left(\mathrm{X}_{1.2}\right)\end{array}$ & 0,644 \\
\hline & $\begin{array}{l}\text { Setiap tugas yang diberikan pimpinan sesuai dengan kemampuan yang } \\
\text { saya miliki }\left(\mathrm{X}_{1.4}\right)\end{array}$ & 0,768 \\
\hline & $\begin{array}{l}\text { Informasi yang diberikan pimpinan jelas sehingga saya dapat } \\
\text { menyelesaikan tugas sesuai dengan keinginan pemimpin }\left(\mathrm{X}_{1.4}\right)\end{array}$ & 0,732 \\
\hline \multirow{4}{*}{$\begin{array}{l}\text { Kepemimpinan } \\
\text { Transformasional } \\
\left(\mathrm{X}_{2}\right)\end{array}$} & $\begin{array}{l}\text { Pimpinan saya selalu memberikan kepercayaan penuh atas tugas yang } \\
\text { diberikan }\left(X_{2.1}\right)\end{array}$ & 0,679 \\
\hline & $\begin{array}{l}\text { Pimpinan saya selalu memberikan motivasi kepada bawahannya agar } \\
\text { mencapai tujuan organisasi }\left(\mathrm{X}_{2.2}\right)\end{array}$ & 0,547 \\
\hline & $\begin{array}{l}\text { Pimpinan saya memiliki kreativitas dan inovasi yang tinggi sehingga } \\
\text { dapat memberikan ide-ide yang baru }\left(\mathrm{X}_{2.3}\right)\end{array}$ & 0,874 \\
\hline & $\begin{array}{l}\text { Pimpinan saya selalu memberikan perhatian dalam pengembangan karir } \\
\text { karyawannya }\left(\mathrm{X}_{2.4}\right)\end{array}$ & 0,916 \\
\hline \multirow{3}{*}{$\begin{array}{l}\text { Keadilan } \\
\text { Organisasi }\left(\mathrm{X}_{3}\right)\end{array}$} & $\begin{array}{l}\text { Pimpinan memberikan jadwal kerja secara adil kepada seluruh karyawan } \\
\left(\mathrm{X}_{3.1}\right)\end{array}$ & 0,920 \\
\hline & $\begin{array}{l}\text { Pimpinan berusaha untuk mendengarkan pendapat karyawan sebelum } \\
\text { membuat keputusan terkait pekerjaan }\left(\mathrm{X}_{3.2}\right)\end{array}$ & 0,847 \\
\hline & $\begin{array}{l}\text { Pimpinan selalu mempertimbangkan hak-hak karyawan ketika membuat } \\
\text { keputusan kerja }\left(X_{3.3}\right)\end{array}$ & 0,937 \\
\hline \multirow{5}{*}{$\mathrm{OCB}\left(\mathrm{Y}_{1}\right)$} & Saya bersedia menolong rekan kerja yang mengalami kesulitan $\left(\mathrm{Y}_{1.1}\right)$ & 0,737 \\
\hline & $\begin{array}{l}\text { Saya sukarela melakukan sesuatu yang bermanfaat bagi perusahaan } \\
\left(\mathrm{Y}_{1.2}\right)\end{array}$ & 0,608 \\
\hline & Saya selalu menjaga hubungan baik dengan rekan kerja $\left(\mathrm{Y}_{1.3}\right)$ & 0,686 \\
\hline & $\begin{array}{l}\text { Saya selalu berpartisipasi dalam berbagai kegiatan yang diselenggarakan } \\
\text { oleh perusahaan }\left(\mathrm{Y}_{1.4}\right)\end{array}$ & 0,839 \\
\hline & Saya menerima setiap kebijakan yang ditetapkan oleh perusahaan $\left(\mathrm{Y}_{1.5}\right)$ & 0,747 \\
\hline \multirow{5}{*}{$\begin{array}{l}\text { Kinerja } \\
\text { Karyawan }\left(\mathrm{Y}_{2}\right)\end{array}$} & Saya mampu menyelesaikan tugas sesuai harapan $\left(\mathrm{Y}_{2.1}\right)$ & 0,712 \\
\hline & $\begin{array}{l}\text { Saya mampu menggunakan waktu seefektif mungkin dalam menangani } \\
\text { pekerjaan }\left(\mathrm{Y}_{2.1}\right)\end{array}$ & 0,711 \\
\hline & Saya selalu berusaha memaksimalkan tingkat kehadiran $\left(\mathrm{Y}_{2.2}\right)$ & 0,587 \\
\hline & $\begin{array}{l}\text { Saya berusaha memberikan pelayanan yang terbaik kepada setiap } \\
\text { pelanggan agar tujuan perusahaan tercapai }\left(\mathrm{Y}_{2.3}\right)\end{array}$ & 0,727 \\
\hline & $\begin{array}{l}\text { Saya mampu menyelesaikan pekerjaan tepat pada waktunya sesuai } \\
\text { dengan rencana yang telah ditetapkan perusahaan }\left(\mathrm{Y}_{2.4}\right)\end{array}$ & 0,821 \\
\hline \multirow{3}{*}{$\begin{array}{l}\text { Komitmen } \\
\text { organisasional } \\
\left(\mathrm{Y}_{3}\right)\end{array}$} & $\begin{array}{l}\text { Hingga saat ini saya merasa tekait secara emosional dengan tempat saya } \\
\text { bekerja }\left(\mathrm{Y}_{3.1}\right)\end{array}$ & 0,859 \\
\hline & Saya merasa rugi jika meninggalkan tempat saya bekerja $\left(\mathrm{Y}_{3.2}\right)$ & 0,851 \\
\hline & $\begin{array}{l}\text { Tetap bekerja dalan organisasi ini merupakan kewajiban moral bagi saya } \\
\left(\mathrm{Y}_{3.3}\right)\end{array}$ & 0,804 \\
\hline
\end{tabular}

Sumber: Data primer diolah, 2017 
Meylinda Triyanthi, dan Made Subudi. Pengaruh Komunikasi Organisasi, Kepemimpin.....

\section{Composite Reliability}

Variabel dinyatakan reliabel jika nilai composite reliability maupun cronbachs alpha diatas 0,70. Hasil output dapat dilihat pada Tabel 11. Berikut:

Tabel 11.

Hasil Uji Composite Reliability

\begin{tabular}{lcc}
\hline \multicolumn{1}{c}{ Variabel } & Composite Reliability & Cronbach 's Alpha \\
\hline Komunikasi organisasi $\left(\mathrm{X}_{1}\right)$ & 0,825 & 0,723 \\
Kepemimpinan & 0,848 & 0,782 \\
Transformasional $\left(\mathrm{X}_{2}\right)$ & 0,929 & 0,887 \\
Keadilan Organisasi $\left(\mathrm{X}_{3}\right)$ & 0,847 & 0,774 \\
OCB $\left(\mathrm{Y}_{1}\right)$ & 0,838 & 0,758 \\
Kinerja Karyawan $\left(\mathrm{Y}_{2}\right)$ & 0,877 & 0,790 \\
Komitmen organisasional $\left(\mathrm{Y}_{3}\right)$ & &
\end{tabular}

Sumber: Data primer diolah, 2017

Hasil output composite reliability maupun cronbachs alpha seluruh variabel penelitian semuanya diatas 0,70. Dengan demikian, dapat dijelaskan bahwa seluruh variabel adalah reliabel.

\section{Evaluasi model struktural atau inner model}

Dalam model struktural ini, terdapat tiga variabel endogen, yaitu: OCB $\left(\mathrm{Y}_{1}\right)$, kinerja karyawan $\left(\mathrm{Y}_{2}\right)$, dan komitmen organisasional $\left(\mathrm{Y}_{3}\right)$. Adapun koefisien determinasi $\left(\mathrm{R}^{2}\right)$ dari masing-masing variabel endogen dapat disajikan dalam Tabel 12. berikut.

Tabel 12.

Nilai $R$-square Variabel Endogen

\begin{tabular}{lc}
\hline \multicolumn{1}{c}{ Variabel } & $\boldsymbol{R}$-square \\
\hline OCB $\left(\mathrm{Y}_{1}\right)$ & 0,474 \\
Kinerja Karyawan $\left(\mathrm{Y}_{2}\right)$ & 0,289 \\
Komitmen organisasional $\left(\mathrm{Y}_{3}\right)$ & 0,312 \\
\hline Sumber: Data primer diolah, 2017
\end{tabular}

Untuk mengukur seberapa baik nilai observasi dihasilkan oleh model dan juga estimasi parameternya, maka perlu menghitung $Q$-square sebagai berikut:

$$
\begin{aligned}
& \mathrm{Q}^{2}=\quad 1-\left(1-\left(\mathrm{R}_{1}\right)^{2}\right)\left(1-\left(\mathrm{R}_{2}\right)^{2}\right)\left(1-\left(\mathrm{R}_{3}\right)^{2}\right) \\
& =1-(1-0,474)(1-0,289)(1-0,312)
\end{aligned}
$$




$$
\begin{array}{ll}
= & 1-(0,526)(0,711)(0,688) \\
= & 1-0,257 \\
= & 0,743
\end{array}
$$

Nilai $Q$-square memiliki rentang nilai $0<\mathrm{Q}^{2}<1$, dimana semakin mendekati 1 berarti model semakin baik. Hasil perhitungan tersebut didapat nilai $Q$-square adalah sebesar 0,743 , sehingga dapat disimpulkan bahwa model memiliki predictive relevance yang baik. Dengan demikian, dapat dijelaskan bahwa 74,3 persen variasi pada kinerja karyawan dan komitmen organisasional dipengaruhi oleh komunikasi organisasi, kepemimpinan transformasional dan keadilan organisasi, serta organizational citizenship behavior, sedangkan 25,7 persen dipengaruhi oleh variabel lain.

\section{Hasil Pengujian Hipotesis}

\section{Partial Least Square}

Tabel 13. berikut merupakan hasil dari uji pengaruh langsung dari masingmasing variabel yang diteliti.

Tabel 13.

Path Coefficients

\begin{tabular}{lccc}
\hline \multicolumn{1}{c}{ Korelasi Antar Variabel } & $\begin{array}{c}\text { Koefisien } \\
\text { Jalur }\end{array}$ & t Statistics & Keterangan \\
\hline Komunikasi organisasi $\left(\mathrm{X}_{1}\right) \rightarrow$ OCB $\left(\mathrm{Y}_{1}\right)$ & 0,235 & 2,038 & Signifikan \\
Kepemimpinan transformasional $\left(\mathrm{X}_{2}\right) \rightarrow$ OCB $\left(\mathrm{Y}_{1}\right)$ & 0,389 & 3,425 & Signifikan \\
Keadilan organisasi $\left(\mathrm{X}_{3}\right) \rightarrow$ OCB $\left(\mathrm{Y}_{1}\right)$ & 0,194 & 2,566 & Signifikan \\
OCB $\left(\mathrm{Y}_{1}\right) \rightarrow$ Kinerja karyawan $\left(\mathrm{Y}_{2}\right)$ & 0,537 & 8,363 & Signifikan \\
OCB $\left(\mathrm{Y}_{1}\right) \rightarrow$ Komitmen organisasional $\left(\mathrm{Y}_{3}\right)$ & 0,559 & 9,014 & Signifikan \\
\hline Sumber: Data primer diolah, 2017 & & &
\end{tabular}

Berdasarkan Tabel 13. menunjukkan bahwa :

- Pengaruh komunikasi organisasi terhadap OCB menghasilkan nilai koefisien jalur sebesar 0,235. Nilai $t$ Statistics didapat sebesar 2,038 (> t kritis 1,96), maka pengaruh komunikasi organisasi terhadap OCB adalah signifikan. 
Meylinda Triyanthi, dan Made Subudi. Pengaruh Komunikasi Organisasi, Kepemimpin.....

Dengan demikian, maka hipotesis $1 \quad\left(\mathrm{H}_{1}\right)$ yang menyatakan bahwa komunikasi organisasi berpengaruh positif dan signifikan terhadap OCB diterima. Penelitian ini mendukung beberapa hasil penelitian sebelumnya dan konsisten dengan hasil penelitian Cutlip et al., (2009), Jefkins (1994), Amanda (2014), Rohmah (2011), serta Ayatse and Ikyanyon (2012) yang menunjukkan bahwa, terdapat hubungan yang positif dan signifikan antara komunikasi organisasi terhadap Organizational Citizenship Behavior karyawan.

- Pengaruh kepemimpinan transformasional terhadap OCB menghasilkan nilai koefisien korelasi sebesar 0,389. Nilai t Statistics didapat sebesar 3,425 (> t kritis 1,96), maka pengaruh kepemimpinan transformasional terhadap OCB adalah signifikan. Dengan demikian, hipotesis $2\left(\mathrm{H}_{2}\right)$ yang menyatakan bahwa kepemimpinan transformasional berpengaruh positif dan signifikan terhadap OCB diterima. Penelitian ini mendukung beberapa hasil penelitian sebelumnya dan konsisten dengan hasil penelitian Prahesti (2016), dan Supit (2016), yang menunjukkan bahwa, terdapat hubungan yang positif dan signifikan antara kepemimpinan transformasional terhadap Organizational Citizenship Behavior karyawan.

- Pengaruh keadilan organisasi terhadap OCB menghasilkan nilai koefisien korelasi sebesar 0,194. Nilai $t$ Statistics didapat sebesar 2,566 (> t kritis 1,96), maka pengaruh keadilan organisasi terhadap OCB adalah signifikan. Dengan demikian, maka hipotesis $3\left(\mathrm{H}_{3}\right)$ yang menyatakan bahwa keadilan organisasi berpengaruh positif dan signifikan terhadap OCB diterima. Penelitian ini 
mendukung beberapa hasil penelitian sebelumnya dan konsisten dengan hasil penelitian Maysarah (2015), Sani (2013), Sanhaji, dkk. (2016), Cahayu dan Adnyani (2015), Suwandewi dan Sintaasih (2016), Tahseen and Akhtar (2016), Awang and Ahmad (2015), Chen and Jin (2014), serta Guh et al. (2013) yang menunjukkan bahwa, terdapat hubungan yang positif dan signifikan antara keadilan organisasi terhadap Organizational Citizenship Behavior karyawan.

- Pengaruh OCB terhadap kinerja karyawan menghasilkan nilai koefisien korelasi sebesar 0,537. Nilai $t$ Statistics didapat sebesar 8,363 (> t kritis 1,96), maka pengaruh OCB terhadap kinerja karyawan adalah signifikan. Dengan demikian, maka hipotesis $4\left(\mathrm{H}_{4}\right)$ yang menyatakan bahwa OCB berpengaruh positif dan signifikan terhadap kinerja karyawan diterima. Penelitian ini mendukung hasil penelitian sebelumnya dan konsisten dengan hasil penelitian Podsakoff et al. (2000), Novelia dkk (2016), Darto (2014), Lestari dkk (2015), Damaryanthi dan Dewi (2016), Chelagat et al. (2015) dan Prahesti (2016) yang menunjukkan bahwa, organizational citizenship behavior berpengaruh positif dan signifikan terhadap kinerja karyawan. Semakin tinggi Organizational Citizenship Behavior, maka kinerja karyawan akan meningkat.

Pengaruh OCB terhadap komitmen organisasional menghasilkan nilai koefisien korelasi sebesar 0,559. Nilai $t$ Statistics didapat sebesar 9,014 (> t kritis 1,96), maka pengaruh OCB terhadap komitmen organisasional adalah signifikan. Dengan demikian, maka hipotesis $5\left(\mathrm{H}_{5}\right)$ yang menyatakan bahwa OCB 
Meylinda Triyanthi, dan Made Subudi. Pengaruh Komunikasi Organisasi, Kepemimpin.....

berpengaruh positif dan signifikan terhadap komitmen organisasional diterima. Penelitian ini mendukung hasil penelitian sebelumnya dan konsisten dengan hasil penelitian Ticoalu (2013), Teresia dan Suyasa (2008), serta Kesuma dan Supartha (2016) yang menunjukkan bahwa, organizational citizenship behavior berpengaruh positif dan signifikan terhadap komitmen organisasional. Semakin tinggi Organizational Citizenship Behavior, maka komitmen organisasional akan meningkat.

Berdasarkan hasil dari koefisien jalur pada hipotesis penelitian, maka dapat digambarkan pengaruh tidak langsung antara variabel komunikasi organisasi, kepemimpinan transformasional dan keadilan organisasi terhadap kinerja karyawan dan komitmen organisasional melalui organizational citizenship behavior. Perhitungan pengaruh antar variabel dirangkum dalam Tabel 14. berikut:

Tabel 14.

Koefisien Pengaruh Tidak Langsung Variabel Penelitian

\begin{tabular}{lcc}
\hline \multicolumn{1}{c}{ Pengaruh Variabel } & $\begin{array}{c}\text { Perhitungan } \\
\text { Pengaruh } \\
\text { Tidak } \\
\text { Langsung }\end{array}$ & $\begin{array}{c}\text { Pengaruh } \\
\text { Tidak } \\
\text { Langsung } \\
\text { Melalui Y1 }\end{array}$ \\
\hline $\begin{array}{l}\text { Komunikasi organisasi }\left(\mathrm{X}_{1}\right) \rightarrow \text { Kinerja karyawan }\left(\mathrm{Y}_{2}\right) \\
\text { Kepemimpinan transformasional }\left(\mathrm{X}_{2}\right) \rightarrow \text { Kinerja karyawan }\end{array}$ & $0,235 \times 0,537$ & 0,126 \\
$\left(\mathrm{Y}_{2}\right)$ & $0,389 \times 0,537$ & 0,209 \\
Keadilan organisasi $\left(\mathrm{X}_{3}\right) \rightarrow$ Kinerja karyawan $\left(\mathrm{Y}_{2}\right)$ & $0,194 \times 0,537$ & 0,104 \\
$\begin{array}{l}\text { Komunikasi organisasi }\left(\mathrm{X}_{1}\right) \rightarrow \text { Komitmen organisasional }\left(\mathrm{Y}_{3}\right) \\
\text { Kepemimpinan transformasional }\left(\mathrm{X}_{2}\right) \rightarrow \text { Komitmen }\end{array}$ & $0,235 \times 0,559$ & 0,131 \\
organisasional $\left(\mathrm{Y}_{3}\right)$ & $0,389 \times 0,559$ & 0,217 \\
Keadilan organisasi $\left(\mathrm{X}_{3}\right) \rightarrow$ Komitmen organisasional $\left(\mathrm{Y}_{3}\right)$ & $0,194 \times 0,559$ & 0,108 \\
\hline Sumber: Data & & \\
\hline
\end{tabular}

Sumber: Data primer diolah, 2017

Berdasarkan Tabel 14. menunjukkan bahwa pengaruh komunikasi organisasi terhadap kinerja karyawan melalui variabel organizational citizenship behavior adalah sebesar 0,126, sedangkan pengaruh tidak langsung variabel 
komunikasi organisasi terhadap komitmen organisasional sebesar 0,131 . Hal ini berarti bahwa pengaruh tidak langsung komunikasi organisasi terhadap komitmen organisasional lebih besar daripada pengaruhnya terhadap kinerja karyawan.

Pengaruh kepemimpinan transformasional terhadap kinerja karyawan melalui variabel organizational citizenship behavior adalah sebesar 0,209, sedangkan pengaruh tidak langsung variabel kepemimpinan transformasional terhadap komitmen organisasional sebesar 0,217 . Hal ini berarti bahwa pengaruh tidak langsung kepemimpinan transformasional terhadap komitmen organisasional lebih besar daripada pengaruhnya terhadap kinerja karyawan.

Pengaruh keadilan organisasi terhadap kinerja karyawan melalui variabel organizational citizenship behavior adalah sebesar adalah 0,104, sedangkan pengaruh tidak langsung variabel organisasi terhadap komitmen organisasional sebesar 0,108. Hal ini berarti bahwa pengaruh tidak langsung organisasi terhadap komitmen organisasional lebih besar daripada pengaruhnya terhadap kinerja karyawan

Dari ketiga variabel tersebut, terlihat bahwa variabel kepemimpinan transformasional yang memiliki pengaruh lebih besar dibandingkan dengan komunikasi organisasi dan keadilan organisasi. Hal ini disebabkan karena variabel kepemimpinan transformasional yaitu Indikator motivasi memiliki nilai paling tinggi jika dibandingkan dengan indikator lainnya.

Hal tersebut disebabkan karena karyawan PT. Yamaha Direct Distribution Sales Bali selalu mendapatkan motivasi yang baik dari pimpinan. Disamping itu karyawan juga merasakan bahwa pimpinan PT. Yamaha Direct Distribution Sales 
Meylinda Triyanthi, dan Made Subudi. Pengaruh Komunikasi Organisasi, Kepemimpin.....

Bali memiliki kreativitas dan inovasi yang tinggi sehingga dapat memberikan ideide yang baru dalam pekerjaan. Oleh karena itu, apabila pimpinan mampu melakukan hal tersebut, maka komitmen organisasional karyawan pun akan meningkat.

\section{SIMPULAN DAN SARAN}

Berdasarkan hasil penelitian maka dapat disimpulkan beberapa hal sebagai berikut: 1) Komunikasi organisasi berpengaruh positif dan signifikan terhadap Organizational Citizenship Behavior. Hal ini berarti bahwa semakin baik penerapan komunikasi organisasi PT. Yamaha Direct Distribution Sales Bali, maka semakin tinggi pula Organizational Citizenship Behavior yang ditunjukkan karyawannya. 2) Kepemimpinan transformasional berpengaruh positif dan signifikan terhadap Organizational Citizenship Behavior. Hal ini berarti bahwa semakin baik penerapan nilai-nilai kepemimpinan transformasional manajer PT. Yamaha Direct Distribution Sales Bali, maka akan semakin tinggi pula Organizational Citizenship Behavior yang ditunjukkan karyawannya. 3) Keadilan organisasi berpengaruh positif dan signifikan terhadap Organizational Citizenship Behavior. Hal ini berarti bahwa semakin adil sikap pemimpin terhadap karyawan PT. Yamaha Direct Distribution Sales Bali, maka akan semakin tinggi pula Organizational Citizenship Behavior yang ditunjukkan karyawannya. 4) Organizational Citizenship Behavior berpengaruh positif dan signifikan terhadap kinerja karyawan. Hal ini berarti bahwa semakin tinggi perilaku Organizational Citizenship Behavior yang dimiliki oleh karyawan PT. Yamaha Direct Distribution Sales Bali maka akan semakin tinggi pula niat karyawan tersebut 
untuk meningkatkan kinerjanya. 5) Organizational Citizenship Behavior berpengaruh positif dan signifikan terhadap komitmen organisasional. Hal ini berarti bahwa semakin tinggi perilaku Organizational Citizenship Behavior yang dimiliki oleh karyawan PT. Yamaha Direct Distribution Sales Bali maka akan semakin tinggi pula komitmen organisasional tersebut.

Saran yang dapat diberikan berdasarkan hasil penelitian adalah sebagai berikut: 1) Sebaiknya pimpinan memberikan tugas yang sesuai dengan kemampuan karyawan serta mampu memberikan informasi yang jelas agar karyawan dapat menyelesaikan tugas sesuai dengan keinginan pemimpin tersebut, sehingga dapat meningkatkan Organizational Citizenship Behavior karyawan. 2) Pemimpin disarankan mampu memberikan kepercayaan penuh atas tugas yang diberikan dan memberikan perhatian dalam pengembangan karir karyawannya, sehingga karyawan akan selalu merasa nyaman saat bekerja dan dapat meningkatkan Organizational Citizenship Behavior karyawan. 3) Sebaiknya pemimpin mendengarkan pendapat karyawan sebelum membuat keputusan terkait pekerjaan, sehingga $O C B$ karyawan akan tercipta dengan sangat baik. 4) Karyawan disarankan agar bersedia secara sukarela melakukan sesuatu yang bermanfaat bagi perusahaan, berpartisipasi dalam berbagai kegiatan yang diselenggarakan oleh perusahaan, dan siap menerima setiap kebijakan yang ditetapkan oleh perusahaan. Terciptanya $O C B$ karyawan harus selalu dijaga oleh pihak manajemen perusahaan. $O C B$ yang terbentuk akan mampu untuk meningkatkan kinerja karyawan serta komitmen organisasional dari karyawan. 5) Karyawan disarankan mampu menggunakan waktu seefektif mungkin dalam 
Meylinda Triyanthi, dan Made Subudi. Pengaruh Komunikasi Organisasi, Kepemimpin.....

menangani pekerjaan dan mampu menyelesaikan pekerjaan tepat pada waktunya sesuai dengan rencana yang telah ditetapkan perusahaan agar dapat meningkatkan kinerja karyawan PT. Yamaha Direct Distribution Sales Bali. 6) Karyawan disarankan agar tetap bekerja dalam organisasi PT. Yamaha Direct Distribution Sales Bali, karena merupakan kewajiban moral, agar komitmen organisasional dapat meningkat.

\section{REFERENSI}

Amanda, A. R. 2014. Pengaruh Employee Communication Terhadap Organizational Citizenship Behavior yang Dimediasi Oleh Employee Engagement Pada Karyawan di Beberapa Fakultas Universitas Trisakti Jakarta: Jurnal Manajemen dan Pemasaran Jasa, Vol. 7, No. 1.

Awang, R. dan Ahmad, W. M. R. W. 2015. The Impact of Organizational Justice on Organizational Citizenship Behavior in Malaysian Higher Education. Mediterranean Journal of Social Sciences, Vol. 6, No. 5.

Ayatse, F. A. and Ikyanyon, D. N. 2012. Organizational Communication, Job Stress and Citizenship Behaviour of IT Employees in Nigerian Universities. Journal of Business Administration Research, Vol. 1, No. 1

Bhutto and Mehboob. 2012. Job Satisfaction as a Predictor of Organizational Citizenship Behavior A Study of Faculty Members at Business Institutes. Jurnal Ilmu Pendidikan, Vol 3, No.9.

Chen, Hong. and Jin, Y. H. 2014. The Effect of organizational justice on organizational citizenship behavior in the Chinese Context. Sage Journals Public Personal Management, Vol. 43, No. 3.

Cutlip, M. S., Allen, C. H. and Glen, B. M. 2009. Effective Public Relation. Edisi kesembilan. Jakarta: Kencana Prenada Media Group

Damaryanthi P. S, A. A. I. dan Dewi, A. A. S. K. 2016. Pengaruh Kecerdasan Emosional, Komitmen Organisasi, dan Organizational Citizenship Behavior Terhadap Kinerja Karyawan FEB. E-Jurnal Manajemen Unud, Vol. 5, No. 2, pp.790-820. 
Darto, M. 2014. Peran Organizational Citizenship Behavior (OCB) dalam Peningkatan Kinerja Individu di Sektor Publik: Sebuah Analisis Teoritis dan Empiris. Jurnal Borneo Administrator, Vol. 10, No. 1.

Guh, W. Y., Lin, S. P., Fan, C. J. and Yang, C. F. 2013. Effects of Organizational Justice on Organizational Citizenship Behaviors: Mediating Effects of Institutional Trust and Affective Commitment. Sage Journals Psychological Reports, Vol. 112, Issue 3.

Hadian, D. dan Adang. 2010. Perilaku Keorganisasian. Bandung: STIE-Pasundan Press.

Huang, C. C., You, C. S. and Tsai, M. T. 2012. A Multidimensional Analysis of Ethical Climate, Job Satisfaction, Organizational Commitment, and Organizational Citizenship Behaviors. Nursing Ethics, Vol. 19, No. 4, pp. 513-529.

Jefkins, F. 1994. Public Relations for Bisnis. Jakarta: Pustaka Binama Pressindo.

Kesuma, I. G. A. W. dan Supartha, I. W. G. 2016. Pengaruh Kepemimpinan Transformasional Terhadap Komitmen Organisasional Dengan Mediasi Organizational Citizenship Behavior dan Kepuasan Kerja. E-Jurnal Manajemen Unud, Vol. 5, No. 6, pp. 3677-3705.

Kumar, K., Bakhshi, A. and Rani, E. 2009. Linking the "Big Five" Personality Domains to Organizational Citizenship Behavior, International Journal of Psychological Studies, Vol. 1, No. 2, pp. 73-81.

Lestari, I. P., Sulianti, D. dan Wulandari, K. G. A. 2015. Pengaruh Self Efficacy dan Organizational Citizenship Behavior (OCB) Terhadap Kinerja Karyawan Dengan Kepuasan Kerja Sebagai Variabel Intervening (Studi Pada Kejaksaan Negeri Jember). Artikel Ilmiah Mahasiswa, 2015.

Mangkunegara, A.P. 2006. Evaluasi Kinerja Sumber Daya Manusia. Jakarta: Refika Aditama. Abdul Halim

Maysarah, S. 2015. Analisis Pengaruh Budaya Organisasi, Keadilan Organisasi, dan Komitmen Organisasi Terhadap Organizational Citizenship Behavior (OCB). Semarang: Jurnal Ekonomi dan Bisnis.

Novelia, M., Swasto, B. dan Ruhana, I. 2016. Pengaruh Komitmen dan Organizational Citizenship Behavior (OCB) Terhadap Kinerja (Studi Pada Tenaga Keperawatan Rumah Sakit Umum Daerah dr. Soegiri Lamongan). Jurnal Administrasi Bisnis (JAB), Vol. 38, No. 2.. 
Meylinda Triyanthi, dan Made Subudi. Pengaruh Komunikasi Organisasi, Kepemimpin.....

Podsakoff, P. M., MacKenzie, S. B., Paine, J. B., Bachrach, D. G. 2000. Organizational Citizenship Behavior: A Critical Review of The Theoretical and Empirical Literature and Suggestions for Future Research. Journal of Management, Vol. 26, No. 3.

Prahesti, D.S. 2016. Pengaruh Kepemimpinan Transformasional Terhadap Kinerja Karyawan Dengan Organizational Citizenship Behavior Sebagai Variabel Mediasi. Tesis. Fakultas Ekonomi Universitas Udayana.

Rohmah, N. 2011. Pengaruh Kepemimpinan, Komitmen Organisasi, dan Komunikasi Interpersonal Terhadap Organizational Citizenship Behavior Karyawan Negeri Sipil Politeknik Ilmu Pelayaran (PIP) Semarang. Artikel Ilmiah. Program Pasca Sarjana Program Studi Magister ManajemenUniversitas Semarang.

Sanhaji, A., Soetjipto, B. E. dan Suharto. 2016. Pengaruh Keadilan Organisasi dan Budaya Organisasi Terhadap Perilaku Kewargaan Organisasi Melalui Komitmen Organisasi dan Kepuasan Kerja. Jurnal Pendidikan: Teori, Penelitian, dan Pengembangan, Vol. 1, No. 5, pp. 917-926.

Sani, A. 2013. Role of Procedural Justice, Organizational Commitment and Job Satisfaction on job Performance: The Mediating Effects of Organizational Citizenship Behavior. International Journal of Business and Management, Vol. 8, No. 15.

Shweta, J., and Srirang, J. 2009. Determinants of Organizational Citizensh ipBehavior: A Review of Literature, Journal of Management and Public Poli cy. Vol. 1 No. 2, pp: 27-36.

Supit, I. Y. I. 2016. Pengaruh Gaya Kepemimpinan Transformasional Terhadap Komitmen Organisasional dan Organizational Citizenship Behavior yang Dimediasi Oleh Kepuasan Kerja. Jurnal Riset Bisnis dan Manajemen, Vol. 4, No. 3, pp: 351-368.

Tahseen, N. and Akhtar, M. S. 2016. Impact of Organizational Justice on Citizenship Behavior: Mediating Role of Faculty Trust. Pakistan Journal of Commerce and Social Sciences 2016, Vol. 10, No. 1, pp. 104-121 